\title{
A Comparative Study on Root Traits of Spring and Winter Canola (Brassica napus L.) under Controlled and Water Stressed Conditions
}

\author{
Muhammad Arif Uz Zaman ${ }^{1} \&$ Mukhlesur Rahman ${ }^{1}$ \\ ${ }^{1}$ Department of Plant Sciences, North Dakota State University, Fargo, ND, USA \\ Correspondence: Mukhlesur Rahman, Department of Plant Sciences, North Dakota State University, Fargo, ND \\ 58108-6050, USA. Tel: 1-701-231-5768. Fax: 1-701-231-8474. E-mail: md.m.rahman@ndsu.edu
}

Received: March 16, 2017

Accepted: May 5, 2017 Online Published: June 15, 2017

doi:10.5539/jas.v9n7p58

URL: https://doi.org/10.5539/jas.v9n7p58

\begin{abstract}
Root system in canola (Brassica napus L.) varies largely in different growth habit types. A study was conducted with five winter and five spring types of canola germplasm. The objective was to identify the gradual change of root traits at different growth habits stages under controlled and water stressed conditions. Two experiments, controlled and water stressed, were conducted in a greenhouse. Data on different root traits were collected at 30 , 40, 50 and 60 days after planting. In controlled experiment, no significant difference was observed for root traits between winter and spring types at 30 days after planting. However, significant variations were appeared for taproot length $\left(\mathrm{F}=10.17^{* * *}\right)$ and root dry weight $\left(\mathrm{F}=16.96^{* * *}\right)$ between winter and spring types at 40 days after planting. All other root parameters such as basal taproot diameter $\left(\mathrm{F}=22.14^{* * *}\right)$, bottom taproot diameter $\left(\mathrm{F}=4.59^{*}\right)$, primary root branches $\left(\mathrm{F}=78.70^{* * *}\right)$ and root vigor $\left(\mathrm{F}=47.18^{* * *}\right)$ were significantly higher in the winter types compared to those of the spring types at 60 days after planting. Growth pattern curves indicated that all the root traits of spring types increased in a steady fashion, where the root traits of winter types increased rapidly after 40 days of planting. In water stressed experiment, the water stress was applied from 20 to 60 days after planting, and data was taken at 60 days after planting. All the root parameters except taproot length were significantly $(\mathrm{P}<0.001)$ lower in the stressed spring and winter plants compared to the control plants. The root growth reduction in stressed winter type germplasms was higher. Basal taproot diameter, bottom taproot diameter, primary root branches, root vigor, and root dry weight were decreased by $43 \%, 63 \%, 19 \%, 31 \%$ and $53 \%$, respectively in stressed winter type plants. In contrast, the root growth reduction of the spring type germplasms were relatively lower. This study indicated that winter type canola generates vigorous root system in comparison to spring types under normal growing conditions, but ceases its root growth rate more than the spring types under water stressed conditions.
\end{abstract}

Keywords: root traits, water stress, winter and spring, B. napus

\section{Introduction}

Root system plays the major role that provides great anchorage and support to the plant, and allows of mining water and nutrient from the soil. Deep and vigorous root system can facilitate higher moisture and nutrient acquisition from the soil, which can increase the yield largely (Marschner, 1998). On the other hand, less vigorous and shallow root system can uptake less amount of moisture and nutrients, which might end up with reduced yield and biomass production. Moreover, shallow root system cannot uptake moisture from deeper soil, and therefore, become vulnerable in drought prone soil. Crop plants use the nutrient and water to perform the necessary metabolic processes, which definitely affect the crop growth and yield positively. For example, maize root system exhibits root growth variation under low phosphorus (P) level in soil and the genotypes having higher lateral root growth were able to uptake more P and maintained good crop stand (Zhu \& Lynch, 2004). Seed yield is positively correlated with longer root system in rice (Steele et al., 2013), canola (M. Rahman \& McClean, 2013), soybean (Brown \& Scott, 1984) and maize (Mackay \& Barber, 1986; Hochholdinger et al., 2008).

Three canola growth habits, including winter, semi-winter, and spring types, differ greatly in terms of shoot morphology, root growth and flowering time. Winter types canola have vigorous root system with higher root length, root diameter, root mass, root branches over the spring types canola (Rahman \& McClean, 2013; Arif Uz Zaman, Mamidi, McClean, \& Rahman, 2016). With these superior root characteristics, root system of winter 
types might be able to cover more area and depth in soil and better access to moisture and nutrient. As the root length of canola is positively correlated with seed yield (Rahman \& McClean, 2013), it can be hypothesized that moisture and nutrient uptake capability is higher in winter types canola, which might play a major role in the higher yield over the spring types. These canola growth habits belong to different genetics groups (Kebedi, Thiagarajah, Zimmerli, \& Rahman, 2010). Therefore, huge variation in the root system of winter and spring canola can serve as significant source of genetic diversity in breeding for high yielding spring canola. Direct selection for root traits in the traditional breeding programs is not very popular yet due to several constraints, including phenotyping, root plasticity etc. Detecting the root phenotypic variation in a large scale field trial regarded as one of the main constraints. In addition, root plasticity or preferential growth towards the area of higher moisture and nutrient may deceive plant breeders in highly heterogeneous soil (Arif Uz Zaman et al., 2016). Identifying quantitative trait loci (QTL) associated with the genomic region that control root variation in canola and subsequent marker assisted selection (MAS) could be an alternative solution. However, appropriate phenotyping of a trait is always very critical in the process of identifying genomic region associated with that trait.

We observed in a preliminary study that there is no major variation in root traits between winter and spring types at early growth stages, rather variations observed in the matured plants. There is no report available that monitored the variations of root growth pattern of winter and spring types canola. The lack of adequate information in this regard limits the scope of proper phenotyping of root traits in a mapping population, as well as traditional selection for root traits in the breeding program. Considering these factors, the objectives of the current study was to detect the plant growth stages at which the variation of root traits initiate and reach to maximum. Our secondary objective was to study the root growth behavior under simulated water stress conditions in spring and winter types canola.

\section{Materials and Methods}

\subsection{Plant Materials}

A total of 10 canola germplasms, five winter types (Wichita, Lindora-00, KSU 8, KSU 10, Regal) and five spring types (Oro, DH45, Kanada, Regent, Wester), were used for this experiment. The plants were grown in long pots $(40 \mathrm{~cm} \times 10 \mathrm{~cm})$ in a greenhouse. A mixture of sand and peat soil in a ratio of 8:2, respectively, were used to grow the plants. The growing media was supplemented with $10 \mathrm{~g} /$ pot Osmocote ${ }^{\circledR}$ slow-release fertilizer (Scott's Company LLC, Marysville, OH, USA). Before potting, the pots were lined with plastic bags to facilitate root extraction procedure. The plastic bags were perforated at the bottom to allow the excess water to drain out. Plants were watered daily to saturate all pots and fertilized with water-soluble 20-20-20 fertilizer once a week.

\subsection{Experimental Design}

Four sets of experiments with the same canola germplasm panel ( 5 winter and 5 spring types) were grown under greenhouse conditions. Each set was planted in a randomized complete block design (RCBD) with four replications. Each pot contains a single canola plant and considered as an experimental unit. These four sets of experiments were grown for four different time periods such as 30 days, 40 days, 50 days, and 60 days after planting.

\subsection{Data Collection}

Data were collected from the plants at 30 days after planting ( $30 \mathrm{~d}), 40$ days after planting $(40 \mathrm{~d}), 50$ days after planting $(50 \mathrm{~d})$, and 60 days after planting $(60 \mathrm{~d})$. Data on number of leaves and stem diameter were taken from the freshly harvested plants. The plants were cut at the base of the root. The pots were taken to root washing zone. The roots with plastic bag were taken out from pots, placed on sink containing a fine plastic net, and the soils covering root masses were washed with running water. This procedure facilitates to avoid root loss during washing. Absorbent papers were used to soak the water from the extracted clean root system and kept them for 1 hour at room temperature. Data on taproot diameter were taken at two points, just at the below of soil level where the first root was initiated (basal taproot diameter) and at $10 \mathrm{~cm}$ below from the place of first root diameter (bottom taproot diameter). Data on bottom taproot diameter were not taken at $30 \mathrm{~d}$. In addition, data on tap root length, and number of root branches were taken. Total root system were visually scored on the basis of root vigor and root mass on a scale of 1-5 according to Rahman and McClean (2013), where score 1: weak bottom and surface roots, score 2: more bottom and surface roots, score 3: intermediate bottom and surface roots, score 4: strong bottom and surface roots, and score 5: the strongest bottom and surface roots (Figure 1). The entire root system of each plant were stored in a perforated plastic bags and dried in $60{ }^{\circ} \mathrm{C}$ until constant weight. Data on root dry weight were recorded for each plant. 


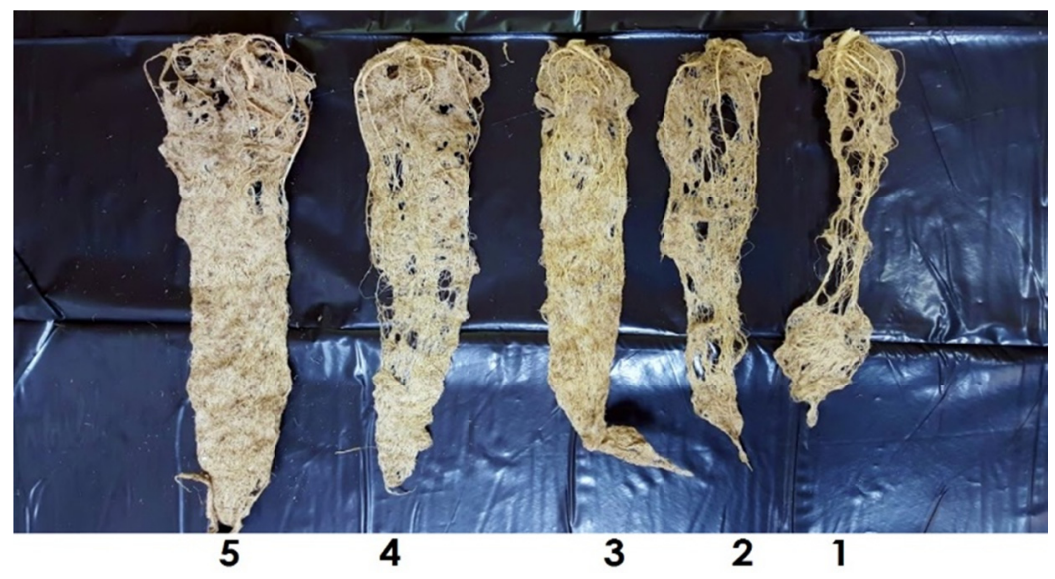

Figure 1. Root vigor score from 1-5 (1: weak bottom and surface roots, 2: more bottom and surface roots, 3: intermediate bottom and surface roots, 4: strong bottom and surface roots, and 5: the strongest bottom and surface roots)

\subsection{Data Analysis}

The root traits of spring types were compared with the winter types within a set. Data were analyzed by using SAS 9.3 statistical software package. Data from each experimental set (30 d, 40 d, 50 d, and 60 d) were analyzed separately to determine if there is any significant difference exists in different root traits between spring and winter types within a set.

\subsection{Water Stress Study}

A water stress experiment was conducted simultaneously with the first experiment using the same spring and winter canola germplasms. The experiment was set in a randomized complete block design with four replications. Water stress was initiated on plants at 20 days after planting by restraining watering until the plants were wilted (approximately 30-35 hours). Moisture level across the wilted pots were taken and averaged to identify the moisture level at which the plants were wilted ( $10 \%$ by volume). The growing media in the pots were allowed to dry at a soil moisture level of $10 \%$ by volume followed by water saturation. This water stress was continued until 60 days after planting. The available soil moisture was measured by a soil moisture meter (Spectrum technologies, Inc.). Data were taken from the water stressed plants of $60 \mathrm{~d}$ on number of leaves, stem diameter, basal taproot diameter, bottom taproot diameter, taproot length, number of root branches, root vigor, and root dry weight were taken from each plant using the same procedures described above.

\section{Result}

\subsection{Stem Diameter}

At 30 days after planting, winter and spring types plants did not show significant difference for stem diameter (Table 1). However, at $40 \mathrm{~d}$ stem diameter was significantly higher $(\mathrm{p}<0.001)$ in winter types comparing to those of spring types. Stem diameter in winter types was sharply increasing after $30 \mathrm{~d}$ and became stable within $40 \mathrm{~d}$ and $50 \mathrm{~d}$ (Figure 2a). In spring types, stem diameter was increasing relatively slow and steady fashion until flowering time at $40 \mathrm{~d}$.

\subsection{Basal Taproot Diameter}

Basal taproot diameter was not significantly different between winter and spring types at $30 \mathrm{~d}, 40 \mathrm{~d}$ and $50 \mathrm{~d}$ (Table 1). At 60 days after planting, it was found significantly higher $(\mathrm{p}<0.001)$ in winter types compared to the spring types (Table 1, Figure 2b). Basal taproot diameter in both winter and spring types increased with a similar trend until $50 \mathrm{~d}$.

\subsection{Bottom Taproot Diameter}

Significant difference $(\mathrm{p}<0.05)$ in bottom taproot diameter was observed only at $60 \mathrm{~d}$ (Table 1). It remained relatively stable at $40 \mathrm{~d}$ and $50 \mathrm{~d}$ and then started to increase sharply in both winter and spring types (Figure 2c). 


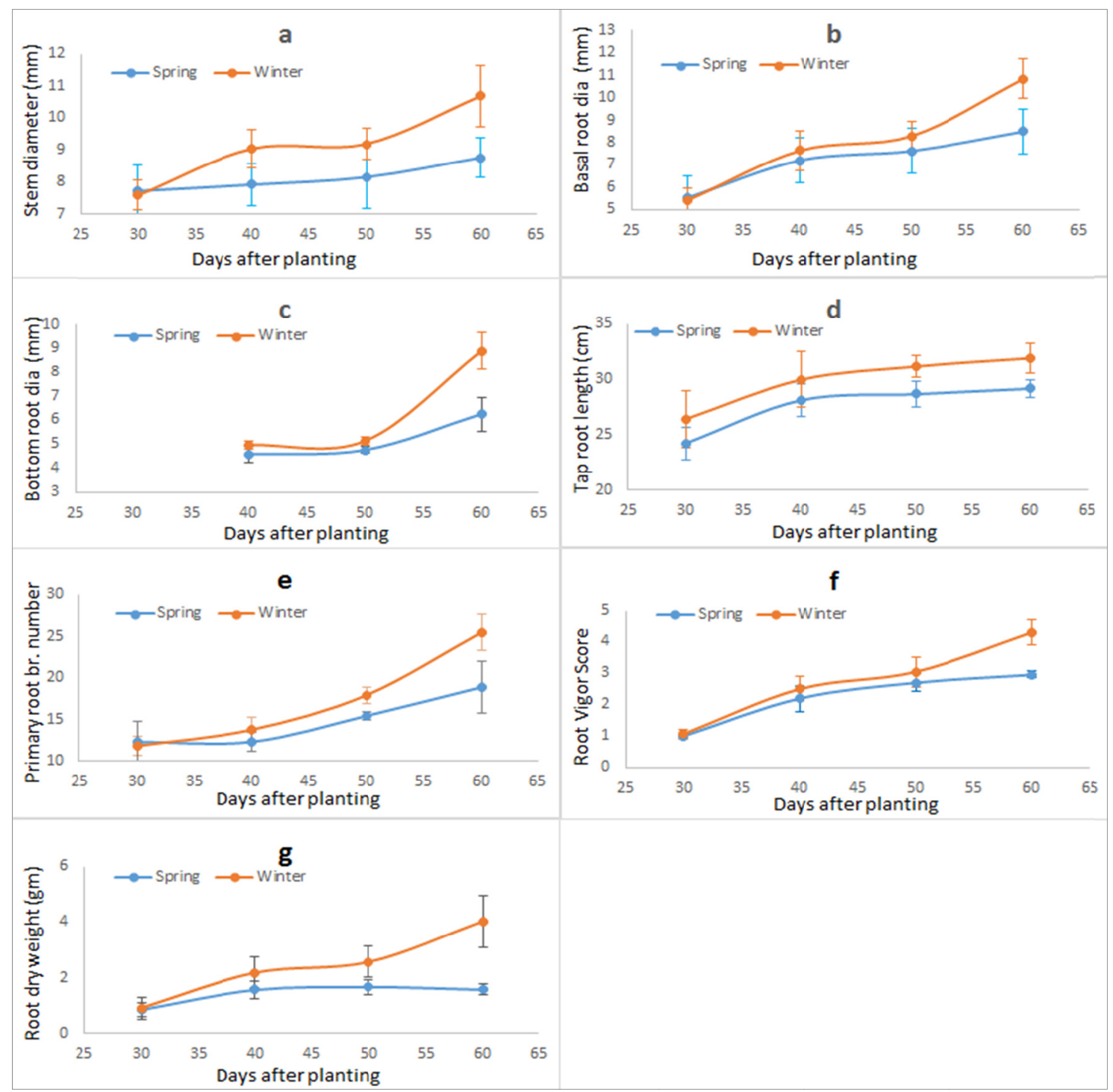

Figure 2. Side by side growth trend of different root parameters in winter and spring types from 30 days to 60 days after planting $(\mathrm{a}=$ Stem diameter, $\mathrm{b}=$ Basal taproot diameter, $\mathrm{c}=$ Bottom taproot diameter, $\mathrm{d}=$ Tap root length, $\mathrm{e}=$ Primary root branch number, $\mathrm{f}=$ Root vigor score, $\mathrm{g}=$ Root dry weight)

\subsection{Taproot Length}

Taproot length was significantly higher $(\mathrm{p}<0.001)$ in winter types than those of spring types from $40 \mathrm{~d}$ (Table 1$)$. Both winter and spring types showed similar response for the taproot length at each timepoint (Figure 2d).

\subsection{Primary Root Branches}

Winter and spring canola types showed a significant difference $(\mathrm{p}<0.001)$ on number of primary root branches at $50 \mathrm{~d}$ and $60 \mathrm{~d}$ (Table 1). Number of primary root branches of winter types increased after $40 \mathrm{~d}$ where it remained constant in spring types followed by an increase of root branches (Figure 2e).

\subsection{Root Vigor Score}

Root vigor was found to be higher in winter types comparing to those of the spring types in all four-time periods. However, winter types exhibited significantly $(\mathrm{p}<0.001)$ higher root vigor at $50 \mathrm{~d}(\mathrm{p}<0.05)$ and $60 \mathrm{~d}(\mathrm{p}<0.001)$ (Table 1, Figure 3). Root vigor increased with a similar trend in both winter and spring types until $50 \mathrm{~d}$ (Figure 2f). A rapid increase at $60 \mathrm{~d}$ was observed only in winter types. 
Table 1. F ratios from analysis of variances for different root traits of winter and spring type canola at different growth stages

\begin{tabular}{llllllll}
\hline & \multicolumn{6}{c}{ Source of variance: Type (Winter vs Spring) } \\
\cline { 2 - 7 } Days after planting & Stem Dia & $\begin{array}{l}\text { Basal } \\
\text { taproot dia }\end{array}$ & $\begin{array}{l}\text { Bottom } \\
\text { taproot dia }\end{array}$ & $\begin{array}{l}\text { Tap root } \\
\text { length }\end{array}$ & $\begin{array}{l}\text { Primary root } \\
\text { br. number }\end{array}$ & $\begin{array}{l}\text { Root vigor } \\
\text { score }\end{array}$ & $\begin{array}{l}\text { Root dry } \\
\text { weight }\end{array}$ \\
\hline $30 \mathrm{~d}$ & 0.44 & 0.04 & - & 2.64 & 0.44 & 1.14 & 0.04 \\
$40 \mathrm{~d}$ & $16.32^{* * *}$ & 0.44 & 0.07 & $10.17^{* * *}$ & 1.7 & 2.54 & $16.96^{* * *}$ \\
$50 \mathrm{~d}$ & $12.32^{* * *}$ & 2.95 & 0.36 & $13.77^{* * *}$ & $9.87^{* * *}$ & $4.58^{*}$ & $30.32^{* * *}$ \\
$60 \mathrm{~d}$ & $23.03^{* * *}$ & $22.14^{* * *}$ & $4.59^{*}$ & $14.3 * * *$ & $78.7^{* * *}$ & $47.18^{* * *}$ & $73.95^{* * *}$ \\
\hline
\end{tabular}

Note. ${ }^{*}=$ significant at 0.05 level; $* * *=$ significant at 0.001 level.

\subsection{Root Dry Weight}

Roots dry weight of winter types were significantly higher $(p<0.001)$ than the spring types at all stages except $30 \mathrm{~d}$ (Table 1). This trait increased at $50 \mathrm{~d}$ in winter types followed by an increase at $60 \mathrm{~d}$ (Figure $2 \mathrm{~g}$ ). In contrast, root dry weight in spring types increased until $40 \mathrm{~d}$ and remain constant after this period.

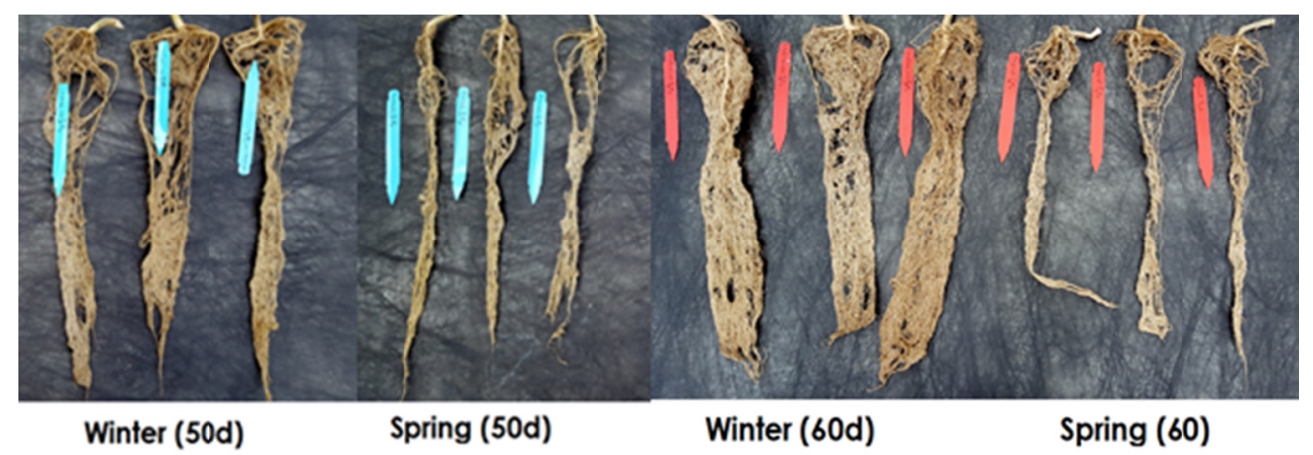

Figure 3. Observed variation between winter and spring type root mass at 50 and 60 days after planting

\subsection{Water Stress Experiment}

Water stress was imposed to spring and winter canola plants at 20 days to 60 days after seeding. Root parameters at 60 days after planting in both winter and spring types were significantly affected under water stressed compared to their normal grown plants (Figure 4). The basal taproot diameter, bottom taproot diameter, root vigor, and root dry weight were significantly $(\mathrm{p}<0.001)$ reduced in stressed plants of both winter and spring types (Table 2). In response to water stress, reduction of different root traits in winter types was higher compared to the spring types. For instance, basal taproot diameter was reduced by $43 \%$ in water stressed winter canola where it is reduced by $32 \%$ in water stressed spring type plants (Figure 5). Similar response was observed for bottom taproot diameter (63\% reduction in winter types, and 53\% in spring types), root vigor score $31 \%$ reduction in winter types, and $25 \%$ in spring types), and root dry weight (53\% reduction in winter types, and $32 \%$ in spring types).

Table 2. F ratios from analysis of variances for different root parameters in winter and spring types canola under control vs water stress condition at 60 days after planting

\begin{tabular}{|c|c|c|c|c|c|c|c|c|c|}
\hline \multirow[b]{2}{*}{ Type } & \multirow{2}{*}{$\begin{array}{l}\text { Days after } \\
\text { planting }\end{array}$} & \multicolumn{8}{|c|}{ Source of variance: Treatment (Drought stress vs control) } \\
\hline & & Stem Dia & $\begin{array}{l}\text { Basal } \\
\text { taproot dia }\end{array}$ & $\begin{array}{l}\text { Bottom } \\
\text { taproot dia }\end{array}$ & $\begin{array}{l}\text { Tap Root } \\
\text { length }\end{array}$ & $\begin{array}{l}\text { Primary Root } \\
\text { Br. number }\end{array}$ & $\begin{array}{l}\text { Root Vigor } \\
\text { score }\end{array}$ & $\begin{array}{l}\text { Root dry } \\
\text { weight }\end{array}$ & $\begin{array}{l}\text { No. of } \\
\text { Leaves }\end{array}$ \\
\hline Spring & $60 \mathrm{~d}$ & $85.11 * * *$ & $43.86^{* * *}$ & $31.85^{* * *}$ & 0.4 & 1.1 & $45.50 * * *$ & $38.13 * * *$ & 3.8 \\
\hline Winter & $60 \mathrm{~d}$ & $87.46^{* * *}$ & $98.18^{* * *}$ & $25.23 * * *$ & 3.38 & $18.72 * * *$ & $138.69^{* * *}$ & $32.86^{* * *}$ & $49.25^{* * *}$ \\
\hline
\end{tabular}

Note. ${ }^{* * *}=$ significant at 0.001 level. 
Number of primary root branches was significantly $(\mathrm{p}<0.001)$ affected only in the winter types water stressed plants and reduced by $19 \%$ from the controlled winter types plants (Table 2, Figure 5). The taproot length was lower in the stressed winter types (5\% lower) and stressed spring types $(1 \%)$ but the rate of reduction was not statistically significant.

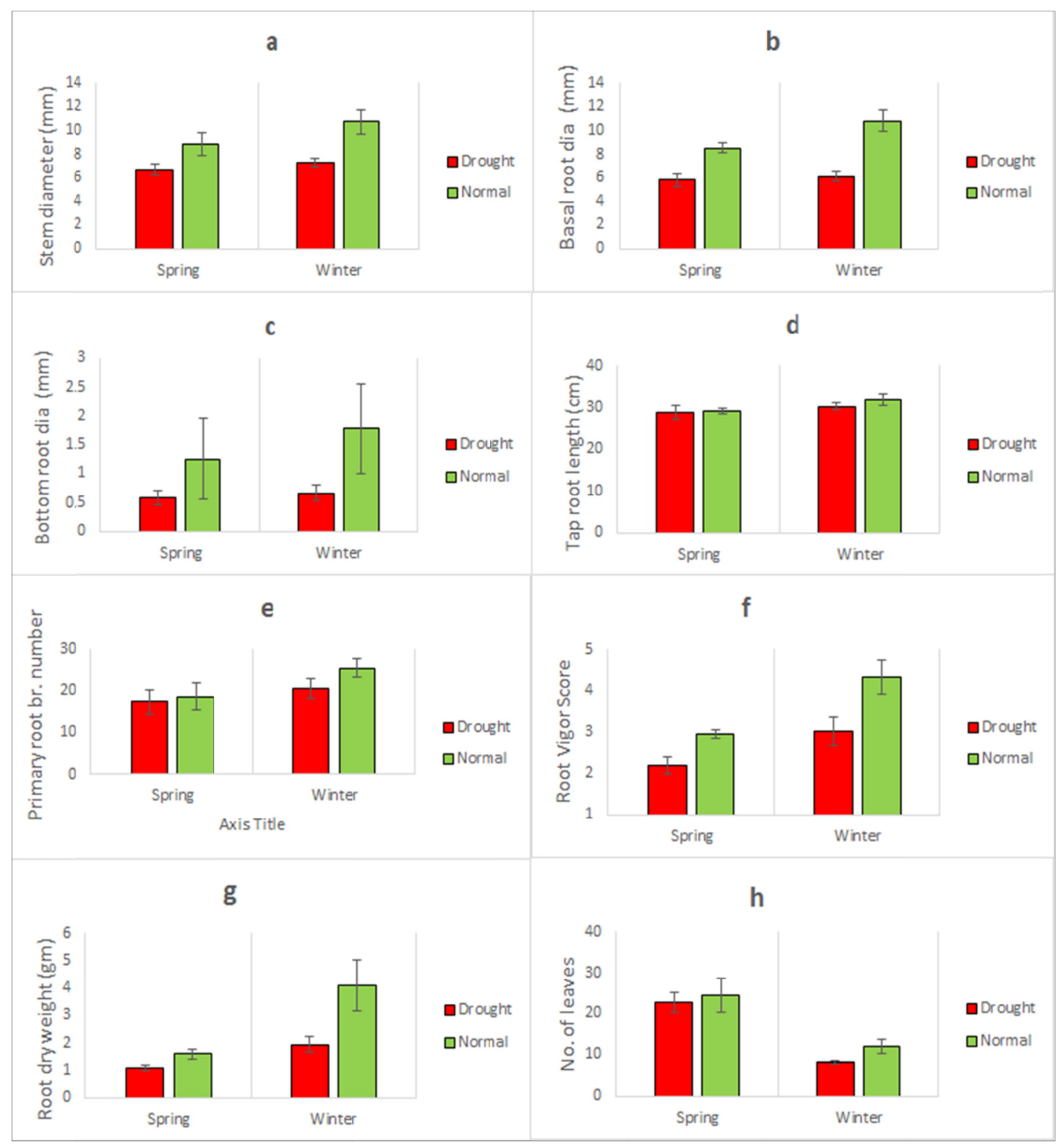

Figure 4. Means of different root parameters with standard deviations in spring and winter type canola under water stress and control condition planting $(\mathrm{a}=$ Stem diameter, $\mathrm{b}=$ Basal taproot diameter, $\mathrm{c}=$ Bottom taproot diameter, $\mathrm{d}=$ Tap root length, $\mathrm{e}=$ Primary root branch number, $\mathrm{f}=$ Root vigor score, $\mathrm{g}=$ Root dry weight, $\mathrm{h}=$ No. of leaves) 


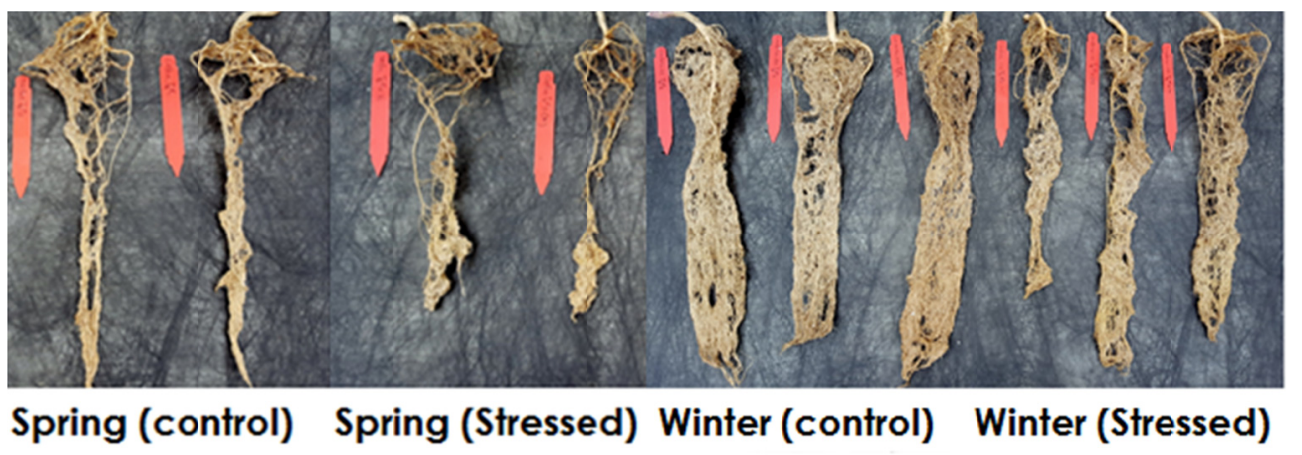

Figure 5. Variation of root mass under drought stress in winter and spring types canola at 60 days after planting

For the above ground plant parts, stem diameter was significantly $(\mathrm{p}<0.001)$ affected both in spring and winter types under water stressed conditions (Table 2). This trait was reduced by $32 \%$ in winter types, and $24 \%$ in spring types water stressed plants (Figure 5). Number of leaves was reduced significantly $(p<0.001)$ by $32 \%$ in winter types. In contrast, the effect of water stress on number of leaves in spring types was not statistically significant.

\section{Discussion}

Two canola growth habits, spring and winter types, are distinct in their root morphology. Winter canola produces higher root mass system with higher root length, lateral root brunches and thicker taproot compared to those of spring canola (Rahman \& McClean, 2013, Arif Uz Zaman et al., 2016). Kebede et al. (2010) reported that the winter types is belong to a very distinct genetic group than the spring canola and can be used as a source of genetic diversity to improve spring canola. Along with other traits, superior root traits of winter canola can be introgressed into spring canola to increase the seed yield. Rahman and McClean (2013) reported that there is big difference of root vigor between winter and spring types canola at flowering stage. However, no report yet available to indicate the growth stage at which the root traits variation occurred and maximized between winter and spring types. Therefore, we have conducted the current study to identify the growth pattern of different root traits in four different time points in both winter and spring types canola. We also conducted a water stressed study to investigate the root growth pattern under stressed conditions.

We did not find any significant differences on root traits between winter and spring types at $30 \mathrm{~d}$. This observation is consistent with our small-scale growth pouch study (unpublished data) in which there was no significant variation of root traits between winter and spring types at early growth stage. Wells and Eissenstat (2003) reported that the root and leaf formation occurs simultaneously in plant until the reproductive stage. Therefore, there is not much difference on root traits at early growth stage of plant. The spring type canola germplasm usually flowers at 40 days after planting in the greenhouse. It is assumed that the plants share more energy to reproductive stage for bud initiation and pod formation. Therefore, roots and vegetative growths are stopped or significantly reduced at reproductive stage. Ledent, Henkart, and Jacobs (1990) reported that leaf initiation is ceased during the tassel formation in maize. Winter canola does not flower without vernalization. At $50 \mathrm{~d}$, the number of primary root branches and root vigor were significantly higher in winter types compared to the spring types. At $60 \mathrm{~d}$, all the root parameters showed significant difference between these two types. The reason of this difference is due to the root and vegetative growth of winter canola plants continue at $40 \mathrm{~d}$ when the spring types start to initiate flower, and stop or reduced the root and vegetative growth. Flowering time changes the energy from vegetative growth to reproductive growth that influences the overall fitness of plant (Michaels, 2009; Pose, Yant, \& Schimd, 2012). These changes of fitness are correlated with many traits including vegetative biomass (Shi et al., 2009; Edwards, Ewers, McClung, Lou, \& Weinig, 2012) and a variety of root traits (Bolaños \& Edmeades, 1993; Mitchell-Olds, 1993; Lou et al., 2007). Cheng et al. (1990) reported that the rate of root growth is higher at early plant developmental stages which greatly decreased during reproductive growth stage. This above ground vegetative growth of winter canola might be an indication of the nature of vigorous root growth at below ground.

We have compared the growth of all root parameters in all time points to understand the nature of variations between winter and spring types. Stem diameter, root dry weight, primary root branches, root vigor, and dry root weight in spring types were increased a little over the time points. In contrast, the winter types had a rapid increase from $40 \mathrm{~d}$ to $50 \mathrm{~d}$, and from $50 \mathrm{~d}$ to $60 \mathrm{~d}$ after planting. This observation indicated that the root trait 
variations between winter and spring types initiated at around $40 \mathrm{~d}$. Rahman and McClean (2013) observed a significant difference of root vigor of winter and spring types during flowering time of spring plants.

With the increasing popularity of molecular breeding methods, high throughput genotyping obtained a substantial improvement in last two decades, however, phenotyping did not receive much attention yet (Zhu, Gore, Buckler, \& Yu, 1008). For the complex traits like roots, phenotyping for large scale association study is even more difficult. The pattern of root growth variation observed in this study will be very useful in the future study of large scale association mapping for different root traits in canola. Phenotyping at 50-60 days after planting will be most effective time to capture maximum amount of phenotypic variation for different root traits in canola. This information might also be helpful in selecting or phenotyping individual root trait for special need.

Crop growth and yield are significantly affected by drought stress (Martin, Waldren, \& Stamp, 2006; Saidi, Ookawa, \& Hirasawa, 2010). Crop root system plays a vital role in avoidance or adapting plants under low moisture content in the soil (Loomis \& Connor, 1992). Modification or alteration of root system under different abiotic stress including drought is a common adaptive measure of plants. In this process, different root traits comprising the whole root system, may respond differently under low water regime (Franco, Bañón, Vicente, Miralles, \& Martínez-Sánchez, 2011; Licht, Wright, \& Lenssen, 2013). Basal taproot diameter and bottom taproot diameter were found significantly higher $(\mathrm{p}<0.001)$ in both spring and winter types of control plants comparing to those of stressed plants. This finding is consistent with those observed in decreasing root diameter under low water conditions in pea (Eavis, 1972), soybean (Read \& Bartlett, 1972), maize (Sharp, Silk, \& Hsiao, 1988; Liang, Sharp, \& Baskin, 1997) and Silene vulgaris (Franco, Arreola, Vicente, \& Martínez-Sánchez, 2008). Sharp et al. (1988) concluded that, decreasing root diameter is an adaptive measure under low moisture regime so that plant concentrates their resources for root elongation to reach water level. A significant reduction was observed in root vigor and root dry weight of winter and spring types grown in water stressed conditions compared to their normal growing conditions. Similar responses were described by Martin et al. (2006) and Saidi et al. (2010) in water stressed plants. In Arabidopsis, reduction of root dry weight under severe water stress has been identified (van der Weele, Spollen, Sharp, \& Baskin, 2000).

We did not find any growth habit difference in terms of root length under control and water stressed conditions. This result is in agreement with Licht et al. (2013) who reported that soybean root elongation was unaffected under water deficit condition. Saidi et al. (2010) observed similar phenomena in maize where no significant difference for total root length was found between different water potential in soil. Franco et al. (2008) studied root and shoot growth in Arabidopsis at very early stage in nutrient-agar media and reported that the root elongation was actually stimulated under a certain limit of water potential deficit. Plants usually improve osmotic adjustment at the root growing zone under low moisture availability which might help plants to maintain their root elongation (Martin et al., 2006).

Upper ground traits such as stem diameter and number of leaves were significantly decreased $(p<0.001)$ in water stressed plants compared to control plants of spring and winter types. To our knowledge, there is no report available on the effect of water stress on stem diameter and leaf number. These changes are expected as many researchers reported that the effect of water stress on shoot growth is higher than the root growth (Saidi et al., 2010; Licht et al., 2013; Franco et al., 2008; van der Weele et al., 2000).

We have observed a differential root growth of spring and winter types canola starting from 40 days after planting. The root growth of spring types significantly reduced at 40 days after planting when the plants start to initiate buds. Winter types do not flower without vernalization and therefore they continue to grow for roots and shoots. All the root traits of the winter type cultivars are highly affected under water stressed conditions over the control experiment. However, this effect is much lower in stressed spring types cultivars compared to their control study. This might be due higher water requirement by the winter type cultivars as they possess higher root and shoot vigor compared to the spring types. In addition, it could be a fact that spring types had higher relative water use efficiency compared to the winter types. However, future investigation is needed to confirm this hypothesis.

\section{References}

Arif Uz Zaman, M., Mamidi, S., McClean, P., \& Rahman, M. (2016). QTL mapping for root vigor and days to flowering in Brassica napus L. Canadian Journal of Plant Science, 97, 99-109. https://doi.org/10.1139/ cjps-2016-0048 
Bolaños, J., \& Edmeades, G. O. (1993). Eight cycles of selection for drought tolerance in lowland tropical maize. II. Responses in reproductive behavior. Field Crops Research, 31, 253-268. https://doi.org/10.1016/ 0378-4290(93)90065-U

Brown, D. A., \& Scott, H. D. (1984). Dependence of crop growth and yield on root development and activity. In S. A. Barber \& D. R. Boulding (Eds.), Roots, Nutrients, Water flux, and Plant Growth (pp. 101-136). ASA Special Publication 49.

Cheng, W., Coleman, D. C., \& Box, J. E. (1990). Root dynamics, production and distribution in agroecosystems on the Georgia piedmont using minirhizotrons. Journal of Applied Ecology, 27, 592-604. https://doi.org/ $10.2307 / 2404304$

Eavis, B. W. (1972). Soil physical conditions affecting seedling root growth. Plant and Soil, 36, 613-622. https://doi.org/10.1007/BF01373511

Edwards, C. E., Ewers, B. E., McClung, C. R., Lou, P., \& Weinig, C. (2012). Quantitative variation in water-use efficiency across water regimes and its relationship with circadian, vegetative, reproductive, and leaf gas-exchange traits. Molecular Plant, 5, 653-668. https://doi.org/10.1093/mp/sss004

Franco, J. A., Arreola, J., Vicente, M. J., \& Martínez-Sánchez, J. J. (2008). Nursery irrigation regimes affect the seedling characteristics of Silene vulgaris as they relate to potential performance following transplanting into semi-arid conditions, Journal of Horticultural Science \& Biotechnology, 83, 15-22. https://doi.org/ 10.1080/14620316.2008.11512341

Franco, J. A., Bañón, S., Vicente, M. J., Miralles, J., \& Martínez-Sánchez, J. J. (2011). Root development in horticultural plants grown under abiotic stress conditions - A review. Journal of Horticultural Science \& Biotechnology, 86, 543-556. https://doi.org/10.1080/14620316.2011.11512802

Hochholdinger, F., Wen, T. J., Zimmermann, R., Chimot-Marolle, P., da Costa e Silva, O., Bruce, W., \& Schnable, P. S. (2008). The maize (Zea mays L.) roothairless 3 gene encodes a putative GPI-anchored, monocot-specific, COBRA like protein that significantly affects grain yield. The Plant Journal, 54, 888-898. https://doi.org/10.1111/j.1365-313X.2008.03459.x

Kebede, B. M., Thiagarajah, M., Zimmerli, C., \& Rahman, H. (2010). Improvement of open pollinated spring rapeseed (Brassica napus L.) through introgression of genetic diversity from winter rapeseed. Crop Science, 50, 1236-1243. https://doi.org/10.2135/cropsci2009.06.0352

Ledent, J. F., Henkart, T., \& Jacobs, B. (1990). Phenology of the maize crop, visual observation of growth and development. Review of Agriculture, 43, 391-408.

Liang, B. M., Sharp, R. E., \& Baskin, T. I. (1997). Regulation of growth anisotropy in well-watered and water-stressed maize roots. 1. Spatial distribution of longitudinal, radial, and tangential expansion rates. Plant Physiology, 115, 101-111. https://doi.org/10.1104/pp.115.1.101

Licht, M. A., Wright, D., \& Lenssen, A. W. (2013). Soybean response to drought. Agriculture and Environment Extension Publications, 190.

Loomis, R. S., \& Connor, D. J. (1992). Crop Ecology: Productivity and management in agricultural systems. Cambridge Univ. Press, Cambridge, UK. https://doi.org/10.1017/cbo9781139170161

Lou, P., Zhao, J., Kim, J. S., Shen, S., Carpio, D. P. D., Song, X., \& Koornneef, M. (2007). Quantitative trait loci for flowering time and morphological traits in multiple populations of Brassica rapa. Journal of Experimental Botany, 58, 4005-4016. https://doi.org/10.1093/jxb/erm 255

Mackay, A. D., \& Barber, S. A. (1986). Effect of Nitrogen on root growth of two corn genotypes in the field. Agronomy Journal, 78, 699-703. https://doi.org/10.2134/agronj1986.00021962007800040028x

Marschner, H. (1998). Role of root growth, arbuscular mycorrhiza, and root exudates for the efficiency in nutrient acquisition. Field Crops Research, 56, 203-207. https://doi.org/10.1016/S0378-4290(97)00131-7

Martin, J. H., Waldren, R. P., \& Stamp, D. L. (2006). Principles of Field Crop Production. Pearson Education, Inc., Upper Saddle River.

Michaels, S. D. (2012) Flowering time regulation produces much fruit. Current Opinion in Plant Biology, 12, 75-80. https://doi.org/10.1016/j.pbi.2008.09.005

Mitchell-Olds, T. (1996). Pleiotropy causes long-term genetic constraints on life-history evolution in Brassica rapa. Evolution, 50, 1849-1858. https://doi.org/10.2307/2410742 
Posé, D., Yant, L., \& Schmid, M. (2012). The end of innocence: flowering networks explode in complexity. Current Opinion in Plant Biology, 15, 45-50. https://doi.org/10.1016/j.pbi.2011.09.002

Rahman, M., \& McClean, P. (2013). Genetic analysis on flowering time and root system in Brassica napus L. Crop Science, 53, 141-147. https://doi.org/10.2135/cropsci2012.02.0095

Read, D. J., \& Bartlett, E. M. (1972). The Psychology of drought resistance in the soybean plant (Glycine max). I. the relationship between drought resistance and growth. Journal of Applied Ecology, 9, 487-499. https://doi.org/10.2307/2402447

Saidi, A., Ookawa, T., \& Hirasawa, T. (2010). Responses of root growth to moderate soil water deficit in wheat seedlings. Plant Production Science, 13, 261-268. https://doi.org/10.1626/pps.13.261

Sharp, R. E., Silk, W. K., \& Hsiao, T. C. (1988). Growth of the maize primary root at low water potentials I. spatial distribution of expansive growth. Plant Physiology, 87, 50-57. https://doi.org/10.1104/pp.87.1.50

Shi, J., Li, R., Qiu, D., Jiang, C., Long, Y., Morgan, C., ... Meng, J. (2009). Unraveling the complex trait of crop yield with quantitative trait loci mapping in Brassica napus. Genetics, 182, 851-861. https://doi.org/10.1534/genetics.109.101642

Steele, K. A., Price, A. H., Witcombe, J. R., Shrestha, R., Singh, B. N., Gibbons, J. M., \& Virk, D. S. (2013). QTLs associated with root traits increase yield in upland rice when transferred through marker-assisted selection. Theoretical Applied Genetics, 126, 101-108. https://doi.org/10.1007/s00122-012-1963-y

van der Weele, C. M., Spollen, W. G., Sharp, R. E., \& Baskin, T. I. (2000). Growth of Arabidopsis thaliana seedlings under water deficit studied by control of water potential in nutrient-agar media. Journal of Experimental Botany, 51, 1555-1562. https://doi.org/10.1093/jexbot/51.350.1555

Wells, C. E., \& Eissenstat, D. M. (2003). Beyond the roots of young seedlings: The influence of age and order on fine root physiology. Journal of Plant Nutrition, 21, 324-334. https://doi.org/10.1007/s00344-0030011-1

Zhu, C., Gore, M., Buckler, E. S., \& Yu, J. (2008). Status and prospects of association mapping in plants. The Plant Genome, 1, 5-20. https://doi.org/10.3835/plantgenome2008.02.0089

Zhu, J., \& Lynch, J. P. (2004). The contribution of lateral rooting to phosphorus acquisition efficiency in maize (Zea mays L.) seedlings. Functional. Plant Biology, 31, 949-958. https://doi.org/10.1071/FP04046

\section{Copyrights}

Copyright for this article is retained by the author(s), with first publication rights granted to the journal.

This is an open-access article distributed under the terms and conditions of the Creative Commons Attribution license (http://creativecommons.org/licenses/by/4.0/). 